\title{
Views from a Different Side of the Jetty: Commodore A.B.F. Fraser-Harris and the Royal Canadian Navy, 1946- 1964
}

\section{Michael Whitby ${ }^{1}$}

Le Commodore Fraser-Harris a essayé de favoriser le changement, tentant en particulier de modifier la mentalité " petit bateau » de la Marine royale canadienne, qu'il pensait limiter le potentiel de la marine comme instrument de politique nationale. Pour des raisons institutionnelles et personnelles il n'a pas réussi. Un historien a tantôt remarqué qu'il est difficile pour une petite marine comme la MRC d'être révolutionnaire, et la carrière de Fraser-Harris semble prouver ce point. Des idées pour évoluer d'une manière différente peuvent être présentées, mais avec un appui fiscal, politique et public limité ainsi qu'une certaine d'inertie institutionnelle, il est difficile de changer l'image traditionnelle. Néanmoins, les leçons de la carrière d'un dirigeant qui a pensé en dehors de la structure des forces traditionnelles peuvent être instructives, particulièrement pour comprendre la dynamique interne d'un établissement tel que la MRC.

Historians revel in personalities who swim against the current. Commodore Alexander Beaufort Fraser Fraser-Harris was one such person. As an original thinker with a completely different foundation of experience than his colleagues in the post-war Royal Canadian Navy (RCN), he challenged, and enjoyed challenging, the precepts of Canadian naval thinking. Fraser-Harris tried to promote change, especially trying to alter the RCN's "small ship" mindset, which he thought limited the potential of the navy as an instrument of national policy. For reasons both institutional and personal he did not succeed. A historian once observed that it is difficult for smaller navies like the RCN to be

1 Much of this study is based upon research for the Official History of the RCN, 1945-1968, and has benefited from discussion with Dr. Isabel Campbell, Dr. Jean Martin, Lieutenant (N) Jason Delaney, Dr. Richard Mayne and Pat Whitby. The paper was originally presented at the Centennial Naval History Conference in Halifax in June 2010, and the author is grateful to Peter Haydon and Dalhousie University for that opportunity. Finally, the author thanks Commodore Fraser-Harris and his wife Jean for their hospitality at Bournemouth, U.K. in April 2003, and for their insistence that his official personnel records be made available to researchers. These papers are in National Defence Headquarters, Directorate of History and Heritage (DHH), 93/432.

The Northern Mariner/le marin du nord, XXII No. 1, (January 2012), 1-26 
revolutionary, and Fraser-Harris's career seems to prove that point. ${ }^{2}$ Ideas for a different way ahead can be introduced, but with limited fiscal, political and public support as well as a degree of institutional inertia, it is difficult to alter the traditional template. FraserHarris was also not helped by the fact that some considered him an "outsider"-a naval aviator, a "Brit," a newcomer, and, later, an officer with personal baggage-which marginalized his position. Nonetheless, the lessons from the career of an officer who thought outside the box of traditional force structure can be instructive, especially in understanding the internal dynamics of an institution such as the RCN.

Fraser-Harris's career also serves as a commentary on how individuals are handled by those interested in drawing lessons from the life and profession of an individual. Fraser-Harris was an outgoing, larger than life figure, who revelled in that personality. These traits, combined with an eventful career, have led to a number of myths and legends about his life, not all propagated by Fraser-Harris, which do not stand up to scrutiny. As so often occurs, these inaccuracies are perpetuated to the point they become accepted as fact. This study endeavours to clarify his record; to ensure, in modern parlance, "it is what it was." Furthermore, Fraser-Harris, a self-described maverick, was a controversial figure in the early 1960s when he held important staff positions during a tumultuous period at Naval Service Headquarters (NSHQ). His role in this setting has also been misunderstood, with him portrayed as an uncompromising proponent of naval aviation and aircraft carriers who would do anything, to the point of unprofessional behaviour, to protect and promote his speciality. However, when one considers his thinking over the entirety of his career, not just a portion, a more complete picture emerges. Viewed through a wider, sharper lens, Fraser-Harris's life does not lose any of its lustre, nor controversy; rather, the perspective reaffirms his stature as one of the most intriguing actors in the post-war navy.

Although Canadian by birth Fraser-Harris's upbringing in both life and the navy was thoroughly British. His Scottish parents came to Canada when his father, David Fraser-Harris, a distinguished physician, was appointed dean of physiology at Dalhousie University. Born in Halifax on 16 November 1916, young Fraser-Harris was dispatched to Scotland for schooling at the age of five, and then moved with his family to England in 1924 when his father was forced to retire prematurely due to poor health. ${ }^{3}$ After attending private schools in England and France, at the tender age of thirteen he entered the Royal Naval College at Dartmouth through a Commonwealth scholarship: he was sponsored by Colonel James Layton Ralston, Canada's minister of national defence and a friend of his

2 Lieutenant-Commander (now Rear-Admiral) James Goldrick, RAN to author.

3 Obituary, "David Fraser-Harris, M.D., D.Sc.," The British Medical Journal (16 January 1937); W.J. O’Connor, British Physiologists 1885-1914: A Biographical Dictionary (Manchester 1991), 425-26. During the First World War Professor Fraser-Harris served in uniform as adjutant of Dalhousie University's COTC contingent and wrote a controversial medical history of the Halifax explosion. After retiring to the U.K. he became a prodigious author on medical subjects. 
father's from Nova Scotia. ${ }^{4}$ After the usual appointments as a midshipman and sublieutenant, Fraser-Harris decided to pursue a career in naval aviation and joined the Fleet Air Arm (FAA).

Here arises one of the legends associated with his career. In later life FraserHarris liked to tell of the occasion when, as a young officer in the battle cruiser HMS Repulse, he appeared before his captain to discuss his request to join the Fleet Air Arm. "Don't be silly," his captain apparently admonished him, "there is no future in aviation." Fraser-Harris rounded off the story by adding that this officer was none other than Captain T.S.V. "Tom" Phillips, who famously met his demise on 10 December 1941 when Repulse and the battleship Prince of Wales were sunk by Japanese aircraft off Malaya, symbolizing, along with the attack on Pearl Harbor, the passing of the battleship era in favour of air power. ${ }^{5}$ It was thus a good yarn steeped in irony; but it was not true. Repulse's commanding officer (CO) during Fraser-Harris's appointment was actually Captain J.H. Godfrey, a distinguished officer who later served as director of naval intelligence during the Second World War. Phillips was never captain of Repulse, and there is no evidence that his path ever crossed Fraser-Harris's. Godfrey may well have expressed the same negative opinion about a career in naval aviation - sentiments that were far from unique among the senior echelons of the $\mathrm{RN}$ - but the episode loses most of its lustre when the officer involved was not one of the most famous victims of a weapon he is portrayed as discrediting.

Fraser-Harris had no need to embellish the brilliant record he accrued during the Second World War. One could fill a book with his experiences but the highlights are impressive enough:

- Flying an obsolescent Fairey Skua dive-bomber from an airfield in the Orkney Islands, on 10 April 1940 he participated in an attack on the German light cruiser Königsberg, which was alongside in Bergen, Norway. As "Blue 3," FraserHarris's bomb was one of those witnessed to hit the cruiser, which capsized and became the first major warship to be sunk by aircraft. ${ }^{6}$

- On 25 April 1940 Fraser-Harris's Skua was shot down during a raid on Trondheim. After crash landing, he and his air gunner made a long, dangerous trek back to friendly forces with the help of Norwegian partisans. ${ }^{7}$

- In the summer of 1940 Fraser-Harris served as a relief pilot in the Battle of

4 Later in life, Fraser-Harris said he was sponsored by Nova Scotia premier Angus L. Macdonald, but in 1945 correspondence he names Ralston. Either way, he was wellconnected to the highest level of Nova Scotia society.

5 See obituary in The Daily Telegraph, 8 November 2003, and Fraser-Harris to R. Hughes, 4 August 1993, DHH, 93/432, file 1. Fraser-Harris repeated this account to the author during an interview at Bournemouth, U.K. on 24-25 April 2003. Like others, the author was initially persuaded by this account.

6 See Admiralty, "Norway Combined Operations (Naval) April 5th to June 13th 1940 [Part] III, Naval Air Operations (1)": "Attack on ships at Bergen by 'Skuas' from Hatston," 10th April 1940," The National Archives, (TNA,) ADM 199/479.

7 Lieutenant A.B.F. Fraser-Harris, "Report of Forced Landing in Skua Aircraft," 28 April 1940, DHH, 93/432, file 3 . 
Britain, and thus became one of "The Few" entitled to wear the prestigious Battle of Britain clasp. ${ }^{8}$

- Flying Fairey Fulmar and Supermarine Seafire fighters off the aircraft carriers Argus and Ark Royal he was in the thick of the air fighting around several critical Malta convoys. During this time he was appointed to command No. 807 squadron. ${ }^{9}$

- In November 1942 Fraser-Harris's Seafire was shot down while attacking an airfield outside Oran during Operation Torch. He was held captive by the Vichy French until freed by American forces several days later.

- During 1943-1944, he served as staff officer (operations) for the flag officer naval air stations at the main FAA base at Lee-on-Solent, outside Portsmouth. His responsibilities included co-ordinating the operations of some fifty FAA squadrons and 3,000 aircraft, and he helped plan the massive naval air effort that supported Operation Neptune. ${ }^{10}$

- In 1945 he ran a large FAA training establishment at Simonstown, South Africa, working-up Grumman Hellcat squadrons for operations with the British Pacific Fleet.

When the war ended Fraser-Harris was twenty-eight years old and held the substantive rank of lieutenant-commander. He had fought in Norwegian, British and Mediterranean waters, engaged in aerial combat, been shot down twice, commanded a fighter squadron and a training establishment, and held an important staff appointment. He had been awarded the Distinguished Service Cross and Bar, was Mentioned in Dispatches, earned the Battle of Britain clasp and, in lieu of other decorations, received twenty-one months additional seniority. ${ }^{11}$ This outstanding record gave Fraser-Harris enormous cachet in naval circles. More importantly, it exposed him to experiences and influences far different from those of his future RCN colleagues. In fact, during the early 1960s he was the only flag officer at NSHQ with no planning or operational experience in the Battle of the Atlantic. His war experience was entirely in task groups carrying out a range of fleet operations - most expeditionary in nature - not in small ship, convoy warfare. It is hardly surprising that his thinking sometimes diverged from the mainstream.

8 Interestingly, although Fraser-Harris was awarded the Battle of Britain Clasp he is not listed in the Battle of Britain Aircrew Roll of Honour, perhaps because his squadron was not formally attached to Fighter Command. See http://www.battleofbritain1940.net/bobhsoc/ index.html.

9 Fraser-Harris become extremely embittered and outspoken about heavy losses caused by flying slow, vulnerable Fairey Fulmars from the antiquated carrier Argus, which was often left exposed in the wake of the faster fleet formation, and he thought the strong criticism he voiced affected his prospects in the RN. Author's interview with Fraser-Harris, 24-25 April 2003.

10 S-206, 26 August 1944, DHH, 93/432, file 2.

11 For complete details of Fraser-Harris's RN and RCN careers see John MacFarlane and Robbie Hughes, Canada's Naval Aviators (Shearwater, 1997), 120-21. 
Fraser-Harris first considered transferring to the RCN in the midst of the Second World War. In 1943 he sounded out the possibility with Colonel Ralston, who had again become minister of national defence in 1939, and Ralston advised him to wait until after the war when the "intention to retain a Naval Aviation Branch [was] confirmed." 12 In 1945, after a chance encounter with the Canadian high commissioner to South Africa, another family friend, he was urged to follow through. According to Fraser-Harris:

My reasons for transferring were mixed. Firstly I was invited, and it meant the opportunity of becoming a "bigger fish in a small pond" since the Canadian Naval Aviation was just starting up and the object was to make use of my operational experience. Secondly I was keen on going back to Canada. Thirdly the RN was about to reduce radically in numbers and I would be lucky even to get command of a squadron. Would more probably have been sent back into general service and away from the flying world for a long time. Last but not least, the pay was better! ${ }^{13}$

On 7 January 1947 Fraser-Harris formally entered the RCN, and he was immediately assigned to positions where his aviation experience could be put to good use in leading the newly established air branch through its infancy. After serving for several months as lieutenantcommander (flying) at the Naval Air Section (NAS) Dartmouth, he was double-hatted as commander of No. 1 Training Air Group, meaning he held the two most important positions at the station in terms of the flying program. In July 1948 he was appointed to command the NAS, and in December 1948, upon the station's transfer to the RCN from the Royal Canadian Air Force (RCAF), he was named the first commanding officer of HMCS Shearwater, the new name for the Dartmouth station.

The situation Fraser-Harris found at Dartmouth was in complete contrast to anything he had experienced with the RN. Rather than a long-established, mature organization, Canadian naval aviation was very much a work in progress, and teething problems

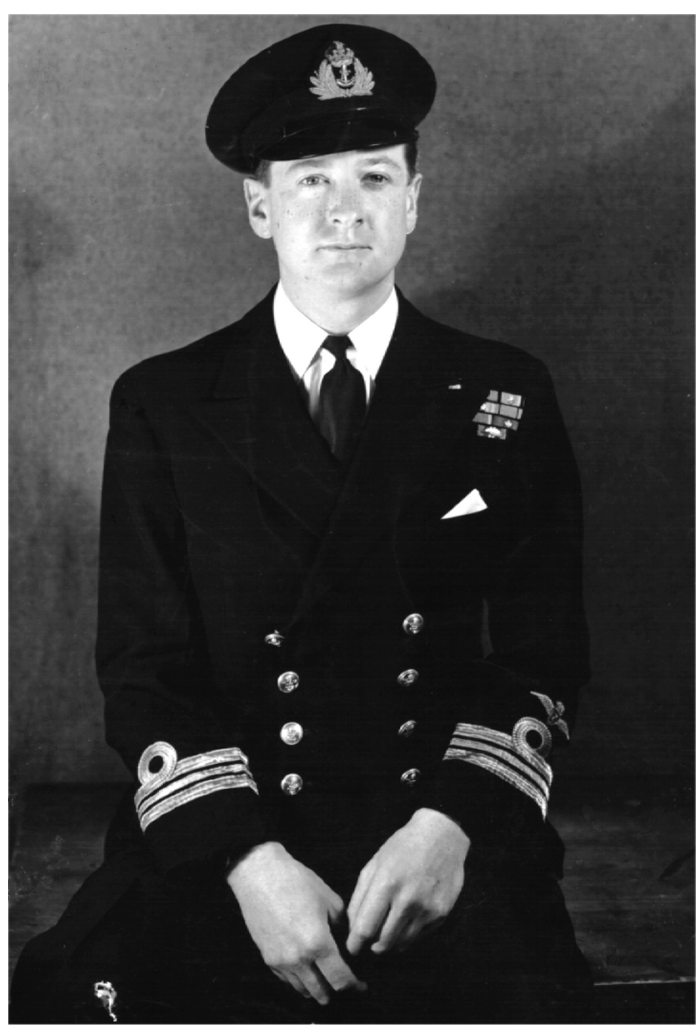

Illustration 1: Lieutenant-Commander FraserHarris at the time of his transfer to the RCN. (D.N.D. photo). abounded. In July 1948 for example, the air crew of No. 825 Squadron, equipped with 
twin-seat Fairey Firefly aircraft, flew an average of only 10.5 hours each, while their brethren in No. 803, which flew single-seat Supermarine Seafires, averaged just eleven hours, making it almost impossible to maintain any kind of proficiency. Likewise maintenance crews, the backbone of the air section, were hampered by a shortage of equipment and tools. ${ }^{14}$ There was not enough housing on the base and that which existed was in poor condition. The RCAF, the air section's landlord until December 1948, did not help by allowing the base infrastructure, including hangars, runways and taxiways, to deteriorate.

Fraser-Harris devoted his efforts to boosting the general professionalism and morale of the base. In August 1948 he reported "The spirit of the section improves daily and the ratings are undoubtedly settling down." Importantly he added, "The Divisional system is getting into its stride and the younger post-war officers are beginning to realize their responsibilities in this matter." Improvement continued and two months later he observed "perhaps the most noticeable change is that salutes and other marks of respect are being paid no longer as a grudging necessity of discipline, but in the spirit of fellowship and pride." Fraser-Harris knew from his RN experience that such small steps were vital to the development of professionalism. ${ }^{15}$ The problems were not completely solved when Fraser-Harris left Shearwater in August 1949 but he had helped put Naval Aviation on the right path. ${ }^{16}$

Fraser-Harris's time at Shearwater also caused the birth of another legend. When he was appointed CO of Shearwater on 1 December 1948, he was also raised from the rank of commander to acting captain. According to a NSHQ report, the temporary promotion was necessary due to the demands of the appointment:

The responsibility of the Commanding Officer of HMCS SHEARWATER will be considerable - he will be in command of approximately 138 officers and 699 men. When the station is at full complement there will be 149 officers and 1264 men approximately. He will be responsible for the administration and operation of not only our entire shore-based air activities but for those of TCA [Trans Canada Airlines], the RCAF and civilian air activities at Dartmouth. ${ }^{17}$

The temporary promotion was approved but has been misconstrued. Just thirtytwo, Fraser-Harris has since been heralded as the "youngest Captain in any

14 Report of Proceedings (ROP), N.A.S. Dartmouth, 8 August 1948, Library and Archives Canada (LAC), RG 24, vol. 11519, file 1926-223/24.

15 ROP, NAS Dartmouth, 8 September and 5 November 1948, ibid.

16 For Naval Aviation's operational effectiveness during this period, see Stuart Soward, Hands to Flying Stations: A Recollective History of Canadian Naval Aviation, 1946-54 (Vancouver, 1993); and Michael Whitby, "Meeting the Challenge: The $19^{\text {th }}$ Carrier Air Group on the RCN's 1949 Spring Cruise," Journal of the Canadian Aviation Historical Society (Fall 2010), 84-89.

17 ACNS to CNS, "Rank of the Commanding Officer and Commander Air, Naval Air Station, Dartmouth, NS," 16 November 1948; and CNS minute, 22 November 1948, both DHH, 93/432, file 3. The commander (air) at Shearwater, Lieutenant-Commander B.S. MacEwen, $\mathrm{RN}$, was also raised to acting commander. 
Commonwealth navy" at the time, ${ }^{18}$ a claim that, intentional or not, evokes unfair comparisons to the famous British naval officer David Beatty who, in the early years of the $20^{\text {th }}$ century, achieved renown as the youngest captain in the $\mathrm{RN}$ and later as the youngest admiral since Horatio Nelson. Fraser-Harris's promotion was only in an acting capacity and chiefly for administrative purposes. He reverted to commander when he left Shearwater and was not promoted substantive captain until 1 January 1954. It is a minor point, but Fraser-Harris's career and his accomplishments at Shearwater do not require such aggrandizement.

When the end of his command at Shearwater approached, Fraser-Harris requested general service outside aviation. ${ }^{19}$ NSHQ responded by enrolling him in the Junior Course in Strategy and Tactics at the United States Naval War College where the quality of his work was considered "excellent," reflecting "a great degree of thought and originality." ${ }^{20}$ After finishing at Newport, Fraser-Harris learned that NSHQ wanted to send him to the United Kingdom (U.K.) for familiarization as commander (air) in a carrier before appointing him to that position in HMCS Magnificent. This was a logical move since it would see him appointed to a position commensurate with his experience and would give him the sea time required for promotion to captain. However, FraserHarris wanted to follow a different path and his arguments against the appointment reveal his attitude towards the place of aviation within the navy:

During the past twelve years of my Naval Service I have not had a sea appointment other than aviation duty in a carrier, and since it is my sincere belief that the major value of Naval Air rests upon the fact that its Officers are primarily Naval Officers whose knowledge and training enables them best to appreciate and employ 'Air' as a specialist function integrated into the over-all function of the Navy, I submit that if circumstances permit I may given sea duty other than in a carrier... ${ }^{21}$

In Fraser-Harris's view, pilots were not just aviators; they were naval professionals. That was an important consideration and demonstrates clearly that he was not a zealous advocate of naval aviation at the cost of everything else. Rather, he thought "Navy first," and that will be important to remember in terms of the policy positions he would adopt later in his career.

In his request for a different appointment Fraser-Harris also offered the opinion that it would be disadvantageous if the RCN's air branch remained in lock-step with the Fleet Air Arm: "It is my belief that the future practices and principles of the operation of Canadian Naval Air tie more in with the United States Navy [USN] than with the Royal Navy, if for no reason other than that of practical logistics." The idea of shedding ties with the RN would have been out of step with most of the RCN establishment. In regard to his own situation, "After 15 years service with the $\mathrm{RN}$, the last eight of which were spent in operation and administration of their 'Air Branch,' I cannot but feel that my

18 Obituary, The Times of London, 19 November 2003, and Department of National Defence (DND), "People in the Navy: CMDRE A.B.F. Fraser-Harris, 1916-2003."

19 A/Captain A.B.F. Fraser-Harris to FOAC, 16 March 1949, DHH, 93/432, file 3.

20 President, U.S. Naval War College to Canadian Naval Attaché, 16 June 1950, ibid.

21 Commander A.B.F. Fraser-Harris to Commodore H.N. Lay, 19 April 1950, ibid. 
education would be better served, and my judgement, and hence my value to the RCN be increased by the substitution of a period of time spent with operational elements of the USN." Fraser-Harris thought he had nothing more to learn from the RN. Finally, in what seems to be an acknowledgement that his background and accent caused him to be identified as a "Brit" and counted against him, he concluded, "In view of the substance of the Mainguy Report and my very recent arrival in Canada, I am not anxious to return to England at this very early stage of my career with the RCN." ${ }^{22}$ He wanted to reinforce his identity as a Canadian.

Accepting that Fraser-Harris and the RCN would benefit by following a different path, and demonstrating tremendous confidence in Fraser-Harris's ability, the chief of the naval staff (CNS), Vice-Admiral H.T.W. Grant, appointed him instead to command of the destroyer HMCS Nootka. ${ }^{23}$ The timing proved fortuitous since it preceded the outbreak of the Korean war by only a few months. Nootka was the first east coast destroyer to deploy to Korea, arriving in theatre in January 1951, and Fraser-Harris succeeded Captain J.V. Brock as commander, Canadian Destroyers Far East. ${ }^{24}$ Again, he thrived at war. NSHQ viewed his post-deployment report as a model of its kind, and the USN awarded him the Legion of Merit for the skill and determination in which he conducted blockade operations. He also received a Mention in Dispatches for his actions against enemy shore batteries and support to guerrilla operations. Perhaps most importantly in the context of his entire career, the Korean experience made Fraser-Harris a staunch supporter of the United Nations (UN) concept, something that, again, must be remembered when we consider his later actions. The fact that he was chiefly involved in task group operations in support of activities ashore also reinforced his Second World War experience. ${ }^{25}$

Fraser-Harris went ashore after Korea. From 1951-53 he served as executive officer of the RCN's major shore establishment, HMCS Stadacona, then from 1953-56 he filled a string of senior naval aviation policy billets at NSHQ: deputy director and then director of naval aviation (DNA), followed by deputy chief of naval aviation (plans). In his appointments at headquarters Fraser-Harris was an influential voice in planning for the recently ordered carrier HMCS Bonaventure's entry into the fleet, which represented a generational step forward in capability and sophistication. In particular, he played an important role in the acquisition of the Grumman CS2F Trackers and MacDonnell F2H-3

22 Ibid.

23 Chief of naval personnel to CNS, 27 April 1950. Rear-Admiral Creery proposed that FraserHarris's appointment as commander (air) of Magnificent be delayed until April 1952 but that never eventuated, likely because he had accrued the necessary experience during his time at Shearwater. DHH, 93/432, file 3.

24 When one considers the professional dynamics of the early post-war RCN, it is interesting to consider that the first commander Canadian Destroyers Far East, Captain J.V. Brock, was a former naval reservist, while the second, Fraser-Harris, was a naval aviator. One can only assume this caused some gnashing of teeth in wardrooms across Canada.

25 Not all was positive since Fraser-Harris received the "displeasure of the Naval Board" after Nootka collided with a tug upon her entry to Esquimalt in July 1951. Naval Secretary, "HMCS 'NOOTKA' - Report of Collision - 31 st July 1951," DHH, 93/432, file 3. 
Banshees, as well as the equipment and facilities necessary to support their operations from the carrier and the shore establishment at Shearwater. Perhaps most importantly, he also instituted a modern aviation safety program. According to Lieutenant-Commander J.R. Burns, RCN who served on his staff when he was DNA:

Gaining improvement [sic (approval?)] for these changes from the many departments involved, once the basic decisions had been reached in his department required strong and dedicated leadership...His office was the usual location where his staff would gather for round table discussion as the pros and cons of all the problems involved in reshaping Naval Aviation were argued. The effectiveness of his tenure in the office of the Director of Naval Aviation became evident as the new equipment came into operation and the air component by the late 1950s and through the 1960s gained its reputation as one of the most efficient ASW units in NATO. ${ }^{26}$

It is worth noting that Fraser-Harris disagreed with the decision to procure Bonaventure. In a report written in 1963 he recalled he had warned his superiors of the shortcomings of a slow and small Colossus-class light fleet carrier (CVL) but noted the government, not the RCN, was primarily responsible for the decision: “...the Navy's choice was then and still would be an Essex class. [Bonaventure] is too small. She is not a good sea boat and she is cluttered up with comparatively useless guns which are seldom used." ${ }^{27}$ Fraser-Harris was not alone in this thinking; nonetheless, the efforts of he and others enabled the RCN to get the most out of the carrier, and perhaps this persuaded him that there was a place for CVLs-albeit ones larger than Bonaventure - in the RCN. ${ }^{28}$

During this period at NSHQ Fraser-Harris also became involved in efforts to protect the future of naval aviation. The original concept formulated during the Second World War had called for a force of two light fleet carriers, and although the acquisition of the second carrier had been cancelled during the dramatic reduction in naval strength after the war, there was still a cadre of officers - not all aviators - who pursued the acquisition of a second carrier. In the mid-1950s, proponents of the two-carrier navy proposed the RCN keep Magnificent instead of returning her to the R.N. when Bonaventure entered service. Fraser-Harris supported this idea but he recognized "Maggie" would be unable to support the fixed-wing aircraft intended for Bonaventure, and instead recommended she be kept as a helicopter carrier $(\mathrm{CVH})$. This placed him at the forefront of those recognizing the potential value of helicopters in anti-submarine warfare (ASW), and Fraser-Harris actually qualified on helicopters later in his career. Many others joined this chorus but, no matter how persuasively they argued their case,

26 Lieutenant-Commander J.R. Burns to Canadian Aviation Hall of Fame, 4 May 2004, author's collection.

27 ACNS (A\&W), "Comments on the Article in McLean's [sic] magazine by Commodore J. Plomer," 29 August 1963, DHH, 120.009 (D19).

28 For example the RN's Hermes class CVLs were larger than Bonaventure, could make 28 knots and were designed to operate 30,000 lb aircraft. See D.K. Brown and George Moore, Rebuilding the Royal Navy: Warship Design Since 1945 (Annapolis, 2003), 22, 42-43; and Norman Friedman, British Carrier Aviation: The Evolution of the Ships and Their Aircraft (Annapolis, 1988), 312-314. 
the government ultimately refused to back any proposal to keep Magnificent in the $\mathrm{CVH}$ role. $^{29}$

Fraser-Harris also became embroiled in two tussles with the RCAF. Since the establishment of the naval air component senior air force officers, who sought control of all military aviation assets, had only begrudgingly accepted its existence, believing the ASW role could be carried out by shore-based maritime patrol aircraft. Senior naval officers led by Commodore H.N. Lay countered by recommending that Canada follow the American model, which would see the RCN control all maritime aviation, including the RCAF's maritime patrol organization. Although the respective service chiefs reached an agreement in September 1952 that preserved both organizations, the following year the CNS, Vice-Admiral E.R. Mainguy, requested Fraser-Harris produce a study on the amalgamation of all maritime air under RCN control. This was ultimately forwarded to the chief of the air staff but, not surprisingly, it was received without comment and went no further. ${ }^{30}$ As this issue percolated, NSHQ learned of RCAF plans to acquire a maritime version of the Bristol Britannia to serve as a very long range (VLR) maritime patrol aircraft. The RCN argued that there was no need for such an aircraft under either Canadian or Supreme Allied Commander Atlantic (SACLANT) war plans and, moreover, thought the aircraft, which entered service as the Canadair CL-28 Argus, would threaten naval aviation by making the carrier appear redundant in the principal capability, midocean air operations. Fraser-Harris led the fight against the Argus, but as with the proposal to absorb RCAF maritime aviation, the navy failed to win over the Chiefs of Staff Committee and senior civilian defence officials. As much as anything these issues point to the fragile position of Canadian naval aviation and its inability to grow beyond a small, one carrier force. Fraser-Harris later predicted, correctly, that this would ultimately lead to the demise of the branch. ${ }^{31}$

As noted previously, Fraser-Harris had attended the U.S. Naval War College in 1949-50, and two later appointments with an academic flavour confirm that senior naval officers at headquarters thought highly of his intellectual ability. Towards the end of his time at NSHQ, Fraser-Harris represented the RCN on Project Lamp Light, a highly

29 For discussions over Magnificent's fate see Michael Whitby, "Vice-Admiral Harry DeWolf: Pragmatic Navalist," in Michael Whitby, Richard Gimblett and Peter Haydon (eds.), The Admirals: Canada's Senior Naval Leadership in the Twentieth Century (Toronto, 2006), 22425; and Michael Whitby, "Fouled Deck: The Pursuit of an Augmented Aircraft Carrier Capability for the Royal Canadian Navy, 1945-64," Canadian Air Force Journal III, nos. 3 and 4 (Summer and Autumn 2010). Despite the strength of the arguments to retain Magnificent in the CVH role it appears that when he became CNS in 1956 DeWolf was under strict instructions from the minister of national defence not to pursue a second carrier in any form.

30 Not all senior naval officers supported this initiative, believing that the RCN could not afford to absorb the entire RCAF maritime patrol infrastructure.

31 In 1956, Fraser-Harris continued the fight against the air force in an article for the British journal The Naval Review that included discussion of "The new factors [in ASW] which make nonsense of the continued existence of [RAF] Coastal Command." "FF-H," "The Flotilla-Battle Fleet of Today," The Naval Review (1956), 272-80. 
sensitive research project sponsored by the USN's chief of naval research and run out of the Massachusetts Institute of Technology (MIT). Comprising some 90 scientists, engineers and military representatives from the U.S., U.K. and Canada, Lamp Lights's mandate was to formulate solutions to the challenges associated with air defence in the nuclear age. It is evident from his post-project evaluation that Fraser-Harris impressed his colleagues and made a significant contribution:

Capt. Fraser-Harris contributed to Project Lamp Light a very sound knowledge of naval strategy, tactics and technical problems, particular those of anti-submarine warfare... This duty provided a unique opportunity for original and constructive professional work in the broadest field of mixed science and naval strategy. Capt. Fraser-Harris exhibited creative and imaginative thinking, tempered by mature judgement based on his naval training and experience. He assisted in the formulation of many far-reaching proposals for improving the defence of North America in areas of naval responsibility. He is a most intelligent and thoughtful officer and a polished gentleman. $^{32}$

After what had to be a valuable intellectual experience, Fraser-Harris attended the National Defence College (NDC) in Kingston where, again, he impressed colleagues and the directing staff. One wonders if these experiences outside the naval mainstream did not isolate Fraser-Harris further from his colleagues in the senior ranks. Nonetheless, they gave him a firm grasp of current strategic thought, and against that backdrop he was alarmed by what he found when his next appointment took him back to sea.

On 3 August 1956 Fraser-Harris achieved a major career goal when he was appointed to command HMCS Magnificent. This was a significant milestone since he became the first aviation specialist to command a Canadian aircraft carrier. Interestingly, it was not until Captain R.H. Falls took over Bonaventure in November 1966 that a second aviation specialist commanded a carrier and, in the end, he and Fraser-Harris were the only two aviators to fill that appointment in an operational capacity. Although this was at odds with USN practice where, by act of Congress, carriers could only be commanded by aviators, it was in line with other navies. Moreover, in the Canadian context there were not always aviators of the required rank and experience to command a carrier. As well, command of a carrier by non-aviation specialists provided opportunity for them to gain sea time in the rank of captain, which was important for the development of senior officers. In this case, however, one wonders if it might not have better if FraserHarris had been appointed the first $\mathrm{CO}$ of Bonaventure, then nearing completion at Harland Wolff's shipyard in Belfast, since Captain H.V.W. Groos, a "fish head," had considerable difficulty in working the new carrier's aviation department up to proficiency while Fraser-Harris had extensive experience doing precisely that with the RN and at Shearwater. ${ }^{33}$

After leading a number of exercises from Magnificent during his first four months in command, Fraser-Harris became unsettled about the fleet's performance, and

32 Undated personnel performance evaluation for Project Lamp Light, DHH, 93/432, file 3.

33 Groos had a reputation as an excellent trainer of men, and it appears that NSHQ put priority on working-up Bonaventure's crew rather than the air department. 
submitted a scathing critique that questioned its suitability for modern ASW. Entitled "Observations on the Composition and Effectiveness of the Royal Canadian Navy," his report was reminiscent of complaints that emanated from a number of RCN escort commanders during the darkest days of the Battle of the Atlantic. As with those critiques, the discussion surrounding his analysis provides an important snapshot of how officers at the sharp end viewed the fleet's ability to conduct ASW at a moment of great dynamism with nuclear-powered submarines (SSN) entering service and strategic missile boats on the horizon. It is also important to consider that Fraser-Harris's assessment came at a time the RCN had a reputation as one of the finest, if not the finest, ASW navies.

In his opening words Fraser-Harris questioned whether any such assessment could even be posited. "It is evident," he commented, "that insufficient analysis of, and comment upon, current equipment and contemporary operating doctrine is finding its way out from the fleet." He noted that over the previous five months Magnificent had participated in three extensive exercise periods, numerous surface and air ASW practices, many controlled hunts as well as more advanced serials. "For the great majority of these exercises," Fraser-Harris revealed, "no records have been kept. Had they been, we would observe that our confidence in the ability of the surface ship to protect a screened body against attack, even from a contemporary submarine under controlled conditions, was sadly misplaced." 34

Fraser-Harris later admitted that he detested the traditional "small ship" mentality that dominated the thinking of senior officers and in his mind inhibited the evolution of the RCN into a balanced force. ${ }^{35}$ That attitude pervades his report. For many years," he noted, "Canada has been justly proud of its 'Little Ship' Navy." "Regrettably," however, "we have got myopic on the subject, believing that little ships are all that we can afford, and all that we need..." In fact, he pointed out that the destroyers, destroyer escorts and frigates utilized by the RCN "are neither particularly cheap, nor particularly useful. For dollar effectiveness return they are probably one of the most expensive military vehicles." In particular, "the retention in service of the older [Tribal class] Destroyer Escorts and [Prestonian class] Frigates is held to represent an unjustified expenditure of money and manpower which could be better employed on the development of new weapon systems." He concluded that "any attempt to use these ships to hunt submarines offensively or in coastal defence against missile firing submarines is simply not realistic." Fraser-Harris thought the new St Laurent class destroyer escorts entering service were a distinct improvement, "possessing a manoeuvrability, detection and attack capability that is vastly superior to the older ships, but they are too slow...against a determined modern submarine," which was "now in a position effectively to discharge her weapons outside the detection range of the surface escort.", 36

As an example of how he was not hide-bound by excessive loyalty to the air

34 CO Magnificent, "Observations on the Composition and Effectiveness of the Royal Canadian Navy," 5 November 1956, 1-9, DHH, 2010/1.

35 Author's interview with Fraser-Harris, 24-25 April 2003.

36 CO Magnificent, "Observations on the Composition and Effectiveness of the Royal Canadian Navy," 5 November 1956, 1-9, DHH, 2010/1. 
branch, Fraser-Harris also expressed concern over naval aviation's role in modern ASW. In reference to fixed wing aircraft, "unless a new more effective device than the sonobuoy can be produced they, too, are losing their anti-submarine capability." Advancements in sensors such as Jezebel and Julie eventually improved the capability of fixed-wing aircraft, but at the time Fraser-Harris thought the future lay with ASW helicopters. In October 1956, Magnificent had stood by to provide a safety deck when the frigate HMCS Buckingham carried out landing trials with a Sikorsky HO4S helicopter, demonstrating the viability of the escort-helicopter marriage. ${ }^{37}$ Fraser-Harris thought the concept had merit, but "The very greatest caution must however be exercised not to allow this concept to take charge and stunt the development of the helicopter as a self-sufficient vehicle." Besides operating helicopters from escorts, as we have seen, he thought the navy should also retain Magnificent as a specialized helicopter carrier. Rather than deploying ASW helicopters singly or in pairs for only limited periods, as would be the case if they were operated strictly from escorts, a larger platform would ensure that they could be utilized in greater numbers thus increasing capability. ${ }^{38}$

Unquestionably influenced by his recent Project Lamp Light and NDC experience, Fraser-Harris insisted that the RCN had "to assess the relative merits of various weapons systems against the background of future fact rather than traditional memory." 39 He noted the nuclear Albacore-hulled submarines under development would achieve submerged speeds exceeding thirty knots and "silent" speeds of up to twenty knots. Moreover, their sensors could achieve detection ranges of up to fifty miles on "existing low frequency sets," and would soon be able to track and attack a target "by purely passive means." This presented a bleak picture for the RCN: "Lest the reader be tempted to brush these figures off as being too far into the future to affect present equipment he is reminded of the unpalatable fact...that the [nuclear-powered submarine] USS Nautilus and the St Laurent are contemporaries, both joining the fleet in the same year, and both designed to cover the same ship-life span in operation." And while nuclear submarines appeared to hold unlimited promise the potential for surface platforms seemed constrained. Fraser-Harris concluded the RCN "must face up to a complete reappraisal of our anti-submarine capability," and reinvest in platforms such as ASW submarines and helicopters. He recognized ASW was a logical role for the RCN but "to meet it we have to stop trailing [in] submarine development and step boldly into the future." To that end "it is believed that the future for the Navy now lies above and beneath the surface of the oceans, not upon the sea, being buffeted by the waves." ${ }^{40}$ In forwarding that view, Fraser-Harris was suggesting nothing less than a sea change in the RCN's force structure, which guided by traditional naval thinking and SACLANT force goals was mainly comprised of the small ships he thought so ineffective.

37 See Shawn Cafferky, Unchartered Waters: A History of the Canadian Helicopter-Carrying Destroyer (Halifax, 2005).

38 CO Magnificent, "Observations on the Composition and Effectiveness of the Royal Canadian Navy," 5 November 1956, 1-9, DHH, 2010/1.

39 The emphasis is Fraser-Harris's.

40 CO Magnificent, "Observations on the Composition and Effectiveness of the Royal Canadian Navy," 5 November 1956, 1-9, DHH, 2010/1. 
Fraser-Harris's radical commentary landed on the desk of the flag officer Atlantic Coast (FOAC), Rear-Admiral R.E.S. Bidwell, with a loud thud. Bidwell's first instinct was to shelve the report. "Although I disagree with a lot of it," he wrote his chief of" staff, Commodore H.L. Quinn, "we might circulate it —on the other hand I think all this stuff about the Tribals being useless, and the frigates worse is hot air, and would not add to the morale of the Fleet...so let it lie, I suggest."41 This, of course, would have confirmed Fraser-Harris's assertion that the RCN was incapable of analyzing its own short-comings. Fortunately, Bidwell's staff saw the wisdom of promoting further study. Commander N. Cogdon, FOAC's assistant chief of staff (air), insisted "discussion on this problem would actually assist morale in the fleet since it would indicate some sort of effort to keep abreast of the times." 42 That view carried the day, and the report was distributed throughout the appropriate east coast establishments; there is no evidence it was shared with NSHQ. Consideration of the report spawned eight detailed analyses as well as a number of shorter commentaries. Space prevents discussion of all these views but a snippet from one demonstrates Fraser-Harris was not alone in his concerns. The acting east coast fleet commander, Captain D.W. Piers - fresh off comprehensive ASW exercises in the U.K., and a confirmed destroyer man who had submitted a similar critique at the height of the Battle of the Atlantic ${ }^{43}$ — supported Fraser-Harris's contention that the fleet mix required alteration if the service was to be prepared for modern A.S.W. Among Piers's recommendations was "to replace our present surface escort force with an A/S [submarine] force, having produced or designed a nuclear A/S submarine," and to invest in $\mathrm{A} / \mathrm{S}$ helicopters but operate them from a large specialized platform such as a $\mathrm{CVH}$ instead of from escorts. ${ }^{44}$

One cannot exaggerate the importance of what had occurred. The RCN's two senior seagoing officers had called for radical changes to the navy's force structure to enable it to provide effective ASW defence against a dangerous threat that was only a few years away. Unbeknownst to Fraser-Harris and Piers, this echoed highly classified discussions that were taking place amongst senior warfare staff at NSHQ who were preparing a study on the best way ahead for the RCN. ${ }^{45}$ All agreed that problems lay ahead but proposed solutions varied, sometimes dramatically. This process would continue over the next few years, and given the divergence of opinions it would have been impossible for all to be satisfied with the outcome. Certainly, Fraser-Harris's

41 FOAC minute, 13 November 1956, DHH, 2010/1.

42 Acting chief of staff (air) minute, 12 December 1956, DHH, 2010/1.

43 See W.A.B. Douglas, Roger Sarty and Michael Whitby, A Blue Water Navy: The Official Operational History of the Royal Canadian Navy in the Second World War, Pt 2 (St. Catharines, 2006), and Richard Mayne, Betrayed: Scandal, Politics and Canadian Naval Leadership (Vancouver, 2008).

44 Senior Canadian officer afloat (Atlantic), "Observations on the Composition and Effectiveness of the Royal Canadian Navy," 21 March 1957, DHH, 2010/1.

45 See Isabel Campbell, "A Transformation in Thinking: the RCN's Naval Warfare Study Group of 1956," in R.H. Gimblett and R.O. Mayne (eds.) People, Policy and Programmes: Proceedings of the $7^{\text {th }}$ Maritime Command Historical Conference (Winnipeg, 2008), 165182. 
bitterness about the small ship mindset was confirmed by the fact that NSHQ refused to cut back the existing force of small ships to allow investment in alternative platforms. ${ }^{46}$

As Fraser-Harris finished penning his critique of the RCN's ASW capability, he embarked upon an operation entirely to the liking of an ardent supporter of the United Nations concept. While in British waters in November 1956 to deliver stores for Bonaventure, Magnificent was urgently recalled home to conduct Operation Rapid Step, the transport of the Canadian UN contingent to Egypt in the wake of the Suez crisis. Magnificent hurried back across the North Atlantic, the crew re-arranging storerooms and moving unnecessary equipment to the upper decks for removal as they proceeded. When she arrived in Halifax on the evening of 13 November, all but essential naval stores were landed, "A" hangar was transformed into a temporary barracks while "B" hangar was filled with Army stores. On the morning of 18 November the last of 217 vehicles was loaded on to the flight deck, and except for the embarkation of 950 soldiers of the 1st Battalion, Queen's Own Rifles of Canada who had flown into Shearwater, "Maggie" was ready to go. Under effective leadership from Fraser-Harris, Magnificent had completed the preparatory stage of Rapid Step five days ahead of schedule. As it was, the operation stalled when the government altered the nature of the mission, and the composition of the contingent was ultimately changed from infantry to support personnel. After standing to in Halifax for the better part of a month, Magnificent had to completely change her load before finally leaving for Suez on 29 December 1956.

As he awaited developments Fraser-Harris had a time to ponder how he would manage the relationship between sailors and soldiers on the long passage to Egypt. In a press interview after Magnificent was under way, Fraser-Harris admitted "the weeks of indecision before the ship sailed for the Middle East were a test of inter-service relations," however, "No friction developed and morale remained high." In his subsequent report to FOAC, Fraser-Harris emphasized that "the policy pursued on board has been one of complete integration between Army and Navy personnel either serving on board or connected with the preparation and operation of the ship." ${ }^{47} \mathrm{He}$ directed that soldiers, wearing white sneakers instead of hob-nailed boots for safety reasons, be taken into the ship's routine, shadowing sailors as they carried out their work. ${ }^{48}$ Fraser-Harris recalled that soldiers "settled very rapidly into the ship's routine, until on the day of our entry into the Mediterranean in warm sunlit water, it was fairly evident, that an on the

46 Officers at NSHQ were making similar arguments. In the "Ad Hoc Study on Naval Aviation," Commodore A.H.G. Storrs, ACNS (A\&W,) and Captain G.C. Edwards, DNA, recommended the RCN decommission its Prestonian class frigates to acquire an Essex class carrier. See Michael Whitby, "Fouled Deck: The Pursuit of an Augmented Aircraft Carrier Capability for the Royal Canadian Navy, 1945-64," Pt 2, Canadian Air Force Journal III, no. 4 (Fall 2010).

47 CO Magnificent to FOAC, 14 January 1957, 1, DHH, 2010/1.

48 CO Magnificent to F.O.A.C., 292241z December 1956, DHH, 81/520/8000 HMCS Magnificent, Middle East Confidential messages Box 61 file 6. This message was a press release. 
spot recruiting drive would have gained the Navy many eager volunteers." 49 The success in integrating personnel drew the attention of Jack Brayley, an "embedded" Globe and Mail reporter, who observed "...the old bubble of inter-service jealousy and rivalry isn't a serious problem." When he queried Fraser-Harris on the subject in the context "of large scale-unification and integration as discussed in countries such as the United States," Fraser-Harris "would only say it's clear from the results of present expedition that Canada can successfully mount an integrated force without anybody losing identity or submerging tradition." 50 This success was no doubt partly due to the confined scope of the experiment, but Fraser-Harris's pro-active leadership made integration work for the duration of the operation.

When Magnificent slid into Port Said in the early afternoon of 10 January 1957, Brayley observed that the carrier was "Emblazoned with big blue and white United Nations insignia so that there can be no doubt about her identity and mission... The only concession to her national identity was [the] White Ensign at her stern." In fact, Egyptians considered the White Ensign as nothing other than British, and Magnificent was virtually identical to the RN light fleet carriers Ocean and Theseus that had entered Port Said as part of the Anglo-French invasion that sparked the crisis. No wonder FraserHarris reported Magnificent's entry caused "considerable consternation." This apparent "Britishness" was undoubtedly reinforced when Fraser-Harris greeted the local Egyptian military commander speaking with a refined English accent and wearing a uniform that, except for Canada flashes and an UN armband, was identical to those worn by British invaders two months previously. Fraser-Harris admitted "the initial impression was not good owing to the similarity of uniforms with the bitterly hated Royal Navy and the White Ensign at our stern." ${ }^{, 51}$ In his post-operation report he observed:

While in no way advocating any lessening of our ties of friendship and kinship with Britain, the sooner our true national status can be established in the international world by the adoption of a Canadian flag and more distinctive uniforms etc., the better, though obviously such steps must be taken in a reasonably slow and dignified manner, so no offence is given to the United Kingdom nor our position within the Commonwealth put in question.

That such attitudes would ignite terrific controversy within a decade with debates over the Canadian national flag and service unification was foreshadowed by RearAdmiral Bidwell's marginalia (which also confirmed Fraser-Harris status as an outsider): "These comments from an Englishman meet with my disapproval." Later, Bidwell tempered his comments: "Very good report, though I disagree about the 'Canadian Flag.", 52

As if being branded "an Englishman" was not enough, during this period FraserHarris also found himself at odds with the naval establishment because of issues in his

49 CO Magnificent to F.O.A.C., 14 January 1957, 1, DHH, 2010/1.

50 Toronto Globe and Mail, 4 January 1957.

51 CO Magnificent to FOAC, 14 January 1957, 3, DHH, 2010/1.

52 CO Magnificent to FOAC, 21 January 1957, p. 8 and FOAC minute n.d., ibid.. 
personal life. Indeed, he later admitted that "it was probably my past sins and 'too social' life which has been my downfall." ${ }^{53}$ From the time Fraser-Harris arrived at NAS Dartmouth he had received consistently high praise in his professional evaluations, but his progress towards higher rank seemed to stall after he was promoted to captain in 1954. Despite glowing evaluations from the FOAC when he left Magnificent-Bidwell described him as "a brilliant and resourceful officer" ${ }^{54}$ - he was not promoted commodore until 1962. Later in life Fraser-Harris admitted that legal complications stemming from the failure of his first marriage, which ended when he was in South Africa at the end of the Second World War, and his divorce from his second wife in the mid1950s to marry a lieutenant in the naval reserve, led to "threats" he would not be promoted beyond captain. Fraser-Harris thought Commodore H.S. Rayner, chief of naval personnel from 1955-57, held him back but it was almost certainly Vice-Admiral H.G. DeWolf, who was CNS when news of Fraser-Harris's marriage strife became known. In conversation with the author DeWolf once expressed outrage at Fraser-Harris's marital situation, and it is probably not a coincidence he was appointed to SACLANT headquarters in Norfolk, Virginia throughout DeWolf's tenure as CNS, only returning to Canada when Rayner succeeded DeWolf in July $1960 .{ }^{55}$ Normally his strong performance in the important appointment as $\mathrm{CO}$ of Magnificent would have boosted his chances for promotion, instead, Fraser-Harris literally found himself an outsider, exiled to the United States.

His personal travails may explain why Fraser-Harris lamented later in life that his career with the RCN "started with a bang, and finished with a fizzle." ${ }^{56}$ If by that he meant he saw himself reaching the very top of the RCN and failed to do so, one can accept the "fizzle"; otherwise the description does not characterize his final years in the navy. As director of naval ship requirements (DNSR) at NSHQ from 1960-1962, and then as assistant chief of naval staff (air and warfare) (ACNS (A\&W)) - the first naval aviator to hold either position - until his retirement in 1964, he was a forceful, intelligent voice during a turbulent period that featured considerable debate over the navy's force structure. Issues being grappled with included an escort replacement program, the requirement for a specialized helicopter platform, whether to acquire conventional or nuclear submarines, how to develop an expeditionary capability, and the future of Bonaventure and the navy's fixed-wing capability. Typical of the Canadian context, options were severely limited by scarce funds and the water was further muddied by the arrival of a new Liberal government in April 1963. It was one of the most dynamic periods in the navy's history, and one in which Fraser-Harris was a vocal participant. Many of the documents from the time are either authored by him or adorned by his tight,

Fraser-Harris to R. Hughes, 17 August 1993, DHH, 93/432, file 1.

54 Rear-Admiral R.S. Bidwell, 2 July 1957, ibid., file 2.

55 At SACLANT Fraser-Harris served as deputy director and then director annual review. During this time he tried, unsuccessfully, to get a helicopter carrier included in the RCN's SACLANT commitment.

56 Fraser-Harris to R. Hughes, 4 August 1993. 
neat script espousing succinct and occasionally sarcastic comments on the matter at hand.$^{57} \mathrm{He}$ won some battles and probably lost more but his thinking was not guided by slavish devotion to fixed wing aviation or aircraft carriers as has been suggested, nor did he attempt to sabotage the General Purpose Frigate (GPF) project. One account of this period portrays an officer unscrupulously attempting to manipulate the process to his own end with complete disregard for the navy. ${ }^{58}$ This criticism is unwarranted, and ignores the fact that his thinking during this period reflects views he had held throughout his career. Moreover, there is no evidence that his actions were anything less than professional. He was unquestionably at odds with colleagues on some matters and he fought hard within the boundaries of the staff system - that was his job - but, as with the rest of his career, it is clear that he had the interests of the navy at heart. It was just that his vision sometimes clashed with that of others. In particular, he thought a fleet with more balance and flexibility would be better suited to Canadian needs. ${ }^{59}$

As director of naval ship requirements, Fraser-Harris headed the organization responsible for formulating the "Ship Characteristics" for various warship designs. The GPF project was at centre stage, and his efforts in this area seem to have been frustrated by a number of factors. The navy, taking advantage of favourable political winds yet to be disrupted by the change in government, was attempting to rush the project through to approval. At a meeting of the GPF characteristics panel in August 1961, the ACNS $(A \& W)$, Rear-Admiral R.P. Welland, "explained to the members the need to hasten the formulation of Ship Characteristics for a General Purpose Frigate. He concluded that we must be fully prepared to commence a construction programme for these ships at short notice." ${ }^{60}$ Against the pressure to move quickly, the technical directorates responsible for designing the new frigate wanted to seize an opportunity they considered long overdue. In a February 1962 memo to the chief of naval technical services, the director general ships, Captain S.M. Davis, observed "In many ways this vessel represents the first opportunity for several years of spreading our wings in a new design. The problems here, and the exciting conflicts involved are, as you are aware, very much in the forefront of

57 For example, his response to a proposal to fit the Prestonian class frigates with a hand held anti-air missile system included language such as "a sad, sad reflection on the pathetic lack of appreciation of air power currently existing in the R.C.N." and "I am afraid this sort of DESPARATION (sic) search for some use for ships with blind disregard for enemy capability, both submarine and air, leaves me cold with fear for those we commit to sea in any future war."

58 Richard Mayne, "Its Own Worse Enemy: Ship Advocacy in the R.C.N., 1963-64," Canadian Naval Review II, no. 3 (Fall 2006), 24-28.

59 This was a finding shared by "The Ad Hoc Report on Naval Objectives," better known as the Brock Report, although it proposed a fleet composed largely of smaller, multi-purpose ships, downplaying the place of fixed wing aviation or the aircraft carrier in future naval warfare. Fraser-Harris reviewed a draft of the Brock Report but his only comment dealt with the concept of buoyancy as it related to various platforms.

60 "Minutes of a Meeting Held in the Office of ACNS (A\&W) on 10 August 1961 to discuss Ship Characteristics for a General Purpose Frigate," LAC, RG 24 (Acc 83-84/167), box 3500, file 8000-DDG, vol 1. 
our activities. However - this excursion from the ruts in which we have been confined by successive DDE [destroyer escort] programmes, present opportunities in...the TechnoAdministrative field." ${ }^{\prime 1}$ They wanted to be innovative but that can cost time and money, and the latter was a serious concern. When he had initiated the project, the CNS, ViceAdmiral H.S. Rayner, had insisted that it be completed within a unit cost of $\$ 33$ million per ship. That proved impossible but the need to keep a close eye on costs restricted options and heightened debate about what was really possible and practicable.

Among others, Fraser-Harris had to navigate these competing influences. As DNSR he worked under ACNS (A\&W) and thus had little choice but to advance RearAdmiral Welland's priorities as quickly as possible. Under pressure to keep things moving, at one point he expressed dismay that he did not have latitude for the normal consultation with various directorates. ${ }^{62}$ Moreover, the rush to approve the ship characteristics meant the design was not completely formulated when initially approved by Naval Board and changes, many of them costly, were continually being introduced. In September 1962, for example, Fraser-Harris submitted an amended list of characteristics that included changes to the hull, bridge arrangements, missile armament and sensors: this, just six months after Naval Board had approved the original design. Given the cost and design constraints he, like others, had to accept compromises. In one instance, he reluctantly accepted the cheaper, lighter 3 -inch/38 main gun over the far more capable 5inch/54. His concern was the provision of adequate air defence, and he was further frustrated when the missile systems and fire control system were later reduced in number and capability. Fraser-Harris also grew concerned that the technical branches had too much influence over the GPF project and that the warfare branches should have greater say in the ship's fighting systems. When he became ACNS (A\&W) in October 1962 he attempted to curtail the power of the technical branches by taking complete control of the formulation of Ships Characteristics. The effort was rebuffed by the vice-chief of the naval staff (VCNS), Rear-Admiral J.V. Brock, but the incident indicates his unease about the entire design/approval process. Actions like that should not be misconstrued as attempts to pull the rug out from under the GPF. In September 1963, when the project was on the verge of being cancelled by the new Liberal government, an officer on FraserHarris's staff submitted a strong critique of a study on the GPF written by Dr. R.J. Sutherland that supported the ship and which the CNS was going to use as evidence before a Parliamentary committee. Rather than investigating the criticisms-some of which Fraser-Harris shared - he thought it would be imprudent to raise additional red flags about the project when the future of the GPF hung in the balance. ${ }^{63}$ If he wanted to undermine the project, surely he would have encouraged and publicized such criticism. And earlier, when weighing in on a discussion among senior staff whether the GPF should be classified as a destroyer or frigate, he maintained it was of no real importance:

61 DG Ships to CNTS, “General Purpose Frigate," 19 February 1962. ibid.

62 "Minutes of a Meeting of the Ship Characteristics Panel Held in the Directorate of Naval Ship Requirements on 25 May 1961 to Discuss First Draft Ship Characteristics for a General Purpose Frigate," ibid.

63 ACNS (A\&W), "Report by Commander E. Gigg on Dr. Sutherland's G.P. Frigate Paper," 4 September 1963, LAC, RG 24 (Acc 83-84/167), box 3776, file 8200-DDG, vol.2. 
"A rose by any other name smells just as sweet!!" This, of course, also implies support for the project.

Fraser-Harris's positions on carriers and naval aviation during this period remained consistent with his previous thinking. We have seen he was a proponent of the ASW helicopter but thought it wrong to operate them solely from escorts or in small detachments from Bonaventure, which he thought was both expensive and limited in terms of capability. He expressed his philosophy succinctly in a submission detailing the characteristics of a proposed ASW Helicopter Carrier:

These characteristics are submitted in the belief that such a ship is essential to the effective operation of helicopters in the $\mathrm{A} / \mathrm{S}$ role, even though a number of these aircraft may be carried and operated from other ships. It is envisaged that the Helicopter carrier will not only provide considerably increased utilization of the helicopters now planned for operation from escorts, but will also greatly increase the number of helicopters available for both escort and attack functions. This ship can fulfil a useful limited war function, either by the carriage of helicopters or VTO [Vertical Take-off] aircraft for Army support, or as a transport for heavy vehicles and military equipment, and to act as a Headquarters ship. ${ }^{64}$

He also thought that if the RCN operated helicopters solely from destroyer escorts, what he termed the "small ship option," it would only be capable of contributing small ASW units piece-meal to SACLANT rather than deploying a larger balanced task group which would better satisfy national requirements-something which in fact occurred after Bonaventure was de-commissioned.

Fraser-Harris's desire for a ship with the flexibility to support expeditionary operations not only reflected his Suez experience, but mirrored the thinking of a cadre of naval planners during this period. In August 1960, Rear-Admiral E.P. Tisdall, then VCNS, proposed "there may be a requirement by 1968 for a commando carrier vessel, not necessarily a converted aircraft carrier. In support of the UN, I should think that such a vessel would require support and escort by at least four fast ships capable of providing gunfire and missile fire at surface, shore and air targets. ${ }^{~} 65$ The latter consideration was probably the genesis of the failed GPF programme, but the idea of acquiring a vessel on the lines of a "commando carrier" capable of supporting land forces in a UN "brush-fire" scenario was tossed around headquarters for months, the question being what type of ship to procure. Fraser-Harris entered the fray shortly after becoming DNSR, and he recommended using the term "Support Ship" instead of "Commando Carrier," "not only to get away from the traditional concept of an aircraft carrier, which has unpopular interservice implications" - one still had to be careful not to provoke the RCAF- "but also because...she is capable of employment in a variety of roles, not necessarily of a combatant nature." Although Fraser-Harris thought a number of platforms were capable of this role, as historian Richard Mayne has pointed out, he thought the Iwo Jima class

64 DNSR, "Preliminary Ship Characteristics A/S Helicopter Carrier and General Purpose Frigate," 7 April 1962, LAC, RG 24 (Acc 83-84/167), box 3500, file 8000-DDG, vol. 1.

65 VCNS, "Ship Replacement Programme," 8 August 1960, LAC, RG 24 (Acc 83-84/167), box 3549, file 8000-35, vol. 4. 
helicopter landing ships (LPH) entering service with the USN were the best ship for the job since their size offered the most flexibility. ${ }^{66}$

Fraser-Harris gained a soap box from which to advance such ideas after Paul Hellyer became minister of national defence (MND) in April 1963. Hellyer wanted Canada to have the capability to launch a "mobile force" that, in his original conception, "is basically an air transportable fighting unit which could be airlifted with its equipment for quick deployment anywhere in the world." In August 1963 he directed the Chiefs of Staff Committee to launch a study into the concept, including a supplementary examination of "the sealift required to transport such a force." ${ }^{\text {"67 }}$ As ACNS (A\&W), Fraser-Harris was appointed naval representative to the Study Group on Mobile Force. ${ }^{68}$ He later acknowledged this experience as a highlight of his career, likely because he was given free-rein to enunciate his ideas. Space does not permit complete discussion of Fraser-Harris's analysis, but his experiences with Korea and Suez made him a firm supporter of the Mobile Force concept, and he thought the navy should have some degree of expeditionary capability. The amount of sea-lift required obviously depended upon the size of the expeditionary force. This was never settled, but the study group report calculated that such a role required the RCN to procure at least one LPH and two vehicle transports with the number rising to six and eight respectively if the navy was required to transport the largest version of the force, a brigade group with tactical air support. ${ }^{69}$

Interestingly, the Mobile Force study seemed to confirm the need to retain or even expand the RCN's carrier force in order to support the tactical air element desired by the minster. This realization came at a time when the future of Canada's aircraft carrier was under scrutiny due both to budget constraints and prognostications that questioned the role of ASW carriers in future warfare. Again, Fraser-Harris found himself at the centre of these debates. Shortly after the Liberal government came to power, at the request of the CNS he chaired a group conducting the ominous sounding Exercise CutBack, which considered the implications of potential budget cuts and proposed areas where savings might be found. One of their main recommendations was that "BONAVENTURE should, for the reason of achieving short term savings, be paid off into reserve," and her CS2F Trackers flown from shore bases while RCAF Arguses covered the mid-ocean. The report emphasised this was seen as a temporary solution that in no way indicated the Naval Staff "do not support the requirement for aircraft carriers in the Royal Canadian Navy," and warned such a move might "inevitably lead to the strongest pressure to abolish Naval Aviation in all its aspects from the Canadian maritime

66 Mayne, "Its Own Worse Enemy."

67 MND, 27 August 1963, H.S. Rayner papers, DHH, 99/31-II-2.

68 Brigadier H.W. Love was Chairman of the study group with Fraser-Harris and Air Commodore H.W. Ball as the other members. Twenty-two staff officers supported their work.

69 "Interim Report of the Study Group on a Mobile Force": App VIII, "A Study to Determine the Sea Transport to Support a Mobile Force," 15 November 1963, H.S. Rayner papers, DHH, 99/31-II-2. 
scene." ${ }^{70}$ If Fraser-Harris was indeed the carrier zealot who would do anything to protect aircraft carriers, it is unlikely he would have submitted such a proposal over his signature, demonstrating, again, that the overall navy picture came first. The next month FraserHarris penned a passionate rebuttal to a RN report that suggested aircraft carriers had no role in future ASW. Among his more salient points were that the situation the RN faced in the Eastern Atlantic was far different than the RCN's in the Northwest Atlantic, and that because the RN had not operated fixed-wing ASW aircraft since the mid-1950s they were unfamiliar with developments such as Jezebel and Julie, which had greatly enhanced their ASW capability. ${ }^{71}$

In February 1964, just months before his retirement, Fraser-Harris submitted a memorandum that encapsulated his vision for the Canadian fleet. The document was sparked by proposals that the navy acquire two or more nuclear submarines. As apparent from his November 1956 review of fleet capability, Fraser-Harris was a strong proponent of nuclear submarines; indeed in May 1958 he had requested temporary duty with an American or British submarine squadron so that he could become more acquainted with the platform. ${ }^{72}$ However, in the fiscal context of 1964 he was concerned their high cost would limit procurement options and skew balance and flexibility across the board:

If we accept atomic submarines at a cost of what will turn out to be in the order of $\$ 90 \mathrm{M}$ a copy when support costs are included, we will find ourselves with a very limited number of these vessels with little operational flexibility and insufficient funds to maintain even one carrier in operation so that the Fleet will be divested of what I believe to be an essential element of maritime operation. I believe, therefore, that the expense of atomic submarines will prohibit the attainment of a Canadian naval force possessing the capability of useful employment in limited war, and transporting and supporting the Army.

Fraser-Harris's proposed "Future Policy" was for the RCN to field an independent ASW task group on each coast; the one on the Atlantic centred around a CVL, the other on a LPH, "which would provide a helicopter element in our Pacific ASW Forces." He thought the RCN should eventually acquire two CVLs to replace Bonaventure - thus remedying the flawed concept of operating just one carrier-and suggested they might even be nuclear powered. ${ }^{73}$ According to other documents he wrote during this period, each task group would have a screen of "Heliporters"-small,

70 ACNS (A\&W), "Staff Consideration of "Exercise CUT-BACK," 25 July 1963, DHH, $81 / 520 / 2200$, vol. 1 . The "Cut-Back" team comprised 13 officers and a defence scientist from the warfare, plans and operational research directorates.

71 ACNS (A\&W), "The Future of the A/S Carrier in EASTLANT," 23 August 1963, DHH, 79/246, folder 59 .

72 Fraser-Harris to CO HMCS Niagara, 20 May 1958, DHH, 93/432, file 1. Fraser-Harris observed, "I am personally convinced of the future effectiveness of submarine warfare and believe that the full exploitation of the depths of the oceans will give to the navies of the future a most powerful and versatile military potential."

73 ACNS (A\&W) to CNS, "Future Policy," 6 February 1964, LAC, RG 24 (Acc 83-84/167), box 4030, file 8885-15, vol. 1 . 
specialized helicopter carrying vessels - and destroyer escorts. The carrier would operate both ASW aircraft and fighters, the latter initially Douglas A4E Skyhawks, which could fulfill both strike and air defence roles, but in the future he thought the RCN could take advantage of emerging VTOL technology. The undersea ASW role would be filled by more affordable conventional submarines. With that composition, the task groups would not only not only be capable of effective ASW but would "have all the flexibility of employment, including troop lift when required..." ${ }^{, 4}$ To Fraser-Harris's enduring disappointment, this concept did not come to fruition-perhaps the "fizzle" he later alluded to - mainly due, in his opinion, to the limited thinking of the proponents of the small ship navy.

Fraser-Harris's final months in uniform coincided with the turmoil over Unification, providing the setting for the greatest myth about his career. Published accounts and correspondence describe him as an outspoken opponent to Unification who turned down promotion to flag rank to resign in protest against the policies of Paul Hellyer. ${ }^{75}$ Contemporary documents tell an entirely different story. Fraser-Harris appears to have developed a professional relationship with Paul Hellyer when he served on the Mobile Force study group but he forged an even closer association with William Lee, Hellyer's notorious assistant who was despised by most senior naval officers. In later life Fraser-Harris explained he sought out Lee so as to understand the thinking of the defence minister's office on various matters. ${ }^{76}$ The two obviously saw eye-to-eye on a wide range of issues since in 1967, three years after Fraser-Harris's retirement from the navy, Lee offered him a job on the Liberal party payroll as a political organizer in the Maritimes for the next federal election. ${ }^{77}$ That indicates that Fraser-Harris had a close relationship with the Hellyer organisation, which, again, placed him out of step with the majority of his naval colleagues. Certainly, he was critical of the serving officers who spoke out publically against the minister's policies, and he thought Rear-Admiral W.M. Landymore, a vocal detractor of Hellyer, should have been court-martialled for his open dissent against Unification. ${ }^{78}$

In the summer of 1964, Fraser-Harris was appointed naval member of the Directing Staff at the National Defence College. However, a three day turnover from his predecessor did not go well, with Fraser-Harris skipping out on most of the scheduled program, leaving an impression of disdain for the job. As a result, the commandant of the college asked the chief of the defence staff to rescind the appointment, concluding "I

74 Ibid.

75 See obituaries in The Daily Telegraph, 8 November 2003, and The Times of London, 19 November 2003.

76 Author's interview with Fraser-Harris, 24-25 April 2003.

77 Fraser-Harris to R. Hughes, 4 August 1993, DHH, 93/432, file 1.

78 Author's interview with Fraser-Harris, 24-25 April 2003. For Landymore's role in the Unification contretemps see Robert H. Caldwell, "Rear-Admiral William L. Landymore: The Silent Service Speaks Out," in Whitby, Gimblett and Haydon, The Admirals, 275-305. 
have no confidence in [Fraser-Harris] and his attitude could only make him a liability to the College. This we could not afford." ${ }^{79}$ The appointment was withdrawn. In the 1990s Fraser-Harris gave a slightly different version of events with nary a word about the problems at NDC:

Finally was offered by the Minister, Paul Hellyer, a straight choice. I could take up the appointment of Naval Member of the Defence College at Kingston, a job away from the politics of Ottawa, and well regarded. In a year I would be recalled to Ottawa and be given one of the top spots and be promoted. The alternative was volunteer retirement if I wished it.

Having lost my zeal for high rank which meant no more sea time and dealing with Treasury Officials and Politicians, for neither of whom I had any enthusiasm, I decided to retire and did so. ${ }^{80}$

So it is clear from his actions and subsequent words that Fraser-Harris did not retire over Unification or Hellyer's policies. It seems he just thought it time to go. Moreover, there was a willingness among the senior brass to have him go ${ }^{81}$ Despite a full 35 -year career, Fraser-Harris was judged to have been released prematurely and received a "Golden Parachute" along with his full pension.

What of Fraser-Harris's supposed opposition to Unification? Evidence that he actually supported the concept came after he retired to the Caribbean to become a charter yachtsman. On 8 November 1966, when resistance to Unification was at a crescendo in the days before a Parliamentary vote, he sent the following telegram to the Canadian Press:

Heard from abroad, the traditionalist uproar against service unification seems somewhat anachronistic... Unification of the three services is probably sound and timely. Let inter-service jealousy, personal rivalry and the extravagance of triplication give way to a single effective and streamlined service in which Canadians can build future history and new tradition in the service of Canada whether by land, sea, air or space... Do we really need the support of such old symbols as flags, kilts or bellbottomed trousers? After thirty-five years of service at sea, in the air and sometimes on the ground, I am convinced that the existence of three services in a relatively small country now creates more problems than it solves. Given loyalty and unselfish co-operation of all hands I believe the Government can create a single service with a

79 Lieutenant-General C. Ware to CDS, 14 July 1964, DHH, 93/432, file 1.

80 Fraser-Harris to R. Hughes, 4 August 1993, DHH, 93/432, file 1.

81 A possible explanation of why some think Fraser-Harris resigned in protest to Unification was the fact that he left the navy in August 1964 at the same time as Rear-Admiral Jeffry Brock, who it was thought was fired by Hellyer due to his opposition to Unification. However, research now indicates that the CNS offered Brock up in response to a request from Hellyer to reduce senior officer strength. Fraser-Harris's voluntary departure also helped to satisfy that objective. See Dr. W.G.D. Lund interview with Vice-Admiral R.L. Hennessey, 20 April 2001, 35-36, DHH. 
common purpose that will more effectively support what I believe should be future Canadian international policies. Let us look forward, not back. ${ }^{82}$

Although it is unclear if Canadian Press published his missive-it did not appear in the Ottawa papers, which would have been its intended destination-his position is clear and probably represented the strongest support for Unification expressed by any senior officer, serving or retired. Again Fraser-Harris's thinking was consistent as the telegram echoes the thoughts he expressed on integration and nationalism while in Magnificent during the Suez Crisis, and his admonition to "look forward, not back" repeats sentiments from his 1956 critique of the composition of the fleet. There is some evidence that Bill Lee may have had a hand in the telegram's origin, but whether so or not, the incident reveals that to the very end Fraser-Harris delighted in swimming against the current.

Fraser-Harris's retirement was as full and varied as his naval career. After leaving the RCN he worked in the charter yacht business shepherding clients round the Caribbean. He then moved to Annapolis, Maryland, where he hung out his shingle as a yacht surveyor and nautical journalist, and helped to coach the sailing team at the U.S. Naval Academy; one can only imagine the tales he spun for the cadets. He also married yet again, for the final time. Fraser-Harris finally settled in the United Kingdom and passed away in Bournemouth, England on 29 October 2003 at 86 years of age. That same year he was inducted into the Canadian Aviation Hall of Fame. ${ }^{83}$ Over a full life FraserHarris had careers in two navies, a rewarding retirement and had been married four times. Reflecting upon his father's life at his memorial service, his son was moved to observe, "Most of us are lucky to have a wife, a job and a life in retirement. To our bewilderment Dad had several of each of these things." 84

What does one make of Fraser-Harris's career with the RCN? The Canadian Aviation Hall of Fame celebrates him as "The Father of Canadian Naval Aviation." 85 However, if such a title should be awarded, and that is questionable, it should properly go to Captains Horatio Nelson Lay and Harry DeWolf who saw the branch through from embryo to birth during the Second World War. Fraser-Harris played a key role in the development of the air branch, but he held the status of a wise uncle or big brother whose experience and leadership guided Canada's naval aviators down the proper flight path. But this study has been more focussed on Fraser-Harris's thinking in terms of improving capability and altering force structure. Here, his influence was not as powerful, and he was unsuccessful in persuading the naval hierarchy to adopt a more balanced force structure, less dependent on the small ships he decried, and with broadened expeditionary

82 Fraser-Harris to Canadian Press, 8 November 1966, DHH, 93/432, file 3.

83 The author was one of those who supported Fraser-Harris's nomination.

84 DND, "People in the Navy: CMDRE A.B.F. Fraser-Harris, 1916-2003."

85 See http://www.cahf.ca/Members and Belt of Orion/members/F_members.htm. 
capability. It is not a question of which viewpoint was right - since history is not in a position to judge because his ideas were never adopted-yet his vision, which still has echoes today, was arguably appropriate for the RCN at that time. That aside, his experience demonstrates how difficult it is for a small navy, with limited funding and lacking popular support, to change course. Nonetheless, professional organizations need people like Fraser-Harris who tilt against the windmills of traditional thinking, and the more high ranked they are the better. Their ideas may not be accepted but by posing them they help to prevent stagnation and an over reliance upon conventional thinking. Ironically, Fraser-Harris's failure to bring about the changes he wanted was probably due to the fact that he was considered an outsider, and was not part of the pre-World War Two cadre that led the RCN through the post-war era. Thus, the very thing that made his thinking stand apart—his RN experience_-probably marginalized him as well. 